\title{
Attitude and Perception Towards Medical Documentation Among Pre-Intern Doctors in Sri Lanka
}

\section{A.B Padeniya}

Ministry of Health

A.I Hathamuna

Ministry of Health

W.S.P Abeysinghe

Ministry of Health

A Gunawardena

Ministry of Health

P Mahipala

Ministry of Health

C Epitakaduwa

Ministry of Health

J.M.S.D Ranasinghe

Ministry of Health

P Colambage

Ministry of Health

H.M.B.H Denuwara

Ministry of Health

A Marasinghe

Ministry of Health

L.J Wijesekara

Ministry of Health

$\mathrm{K}$ Weerasinghe

Ministry of Health

N.D.S.K Wijayarathna ( $\nabla$ dayokavindhya@gmail.com )

University of Colombo

W.I.U Jayawickrama

Ministry of Health

P.K.B Mahesh

Ministry of Health 


\section{Research Article}

Keywords: Attitude and perception, medical documentation, diagnosis card, pre-intern, training

Posted Date: March 7th, 2022

DOI: https://doi.org/10.21203/rs.3.rs-1212541/v1

License: (c) (i) This work is licensed under a Creative Commons Attribution 4.0 International License.

Read Full License 


\section{Abstract}

\section{Introduction}

A properly documented medical record is a vital component in good clinical care. A medical record lies as a core of health information system in the hospital. Medical document is a record pertaining to clinical assessment, medical care, professional judgment and critical thinking by a health professional in relation to providing patient care. There is a paucity of studies in Sri Lankan literature to assess attitudes and competencies among pre-intern doctors on medical documentation.

\section{Aim}

To describe the Attitude and perception towards medical documentation among pre-intern doctors in Sri Lanka

\section{Methods}

A descriptive cross-sectional study was carried out among 641 pre-interns who were eligible for medical internship in 2020. A pre-tested self-administered questionnaire was used to collect data. The objective of the study was to determine attitude and perception towards medical documentation among pre-intern doctors. Pre-interns who joined for the Good Intern Programme, in year 2020 were invited to participate for the study. Descriptive statistical analyses were done.

\section{Results}

Mean age of the participants was 27.6 (SD 1.4) years and majority of them were females (66.5\%). Majority (92.20\%) of pre- interns perceived that if a patient leaves against medical advice, it is a duty of the doctor to issue a diagnosis card to the patient. Majority $(91.73 \%)$ believed that they have to give a diagnosis card even for the simple viral fever. Around $69.42 \%$ of pre- interns have got a chance to participate for any training on writing diagnosis cards within last 3 years while majority $(74.26 \%)$ of them perceived that they have received an adequate training in diagnosis card writing so far. Fifty-eight percent of them specified as they learnt to write diagnosis card by observing it during ward work. Majority $(52.26 \%)$ of the participants perceived that they have satisfactory level of competency in writing a diagnosis card. Meanwhile majority (88.3\%) of participants perceived that they need a training on proper way of writing a diagnosis card prior to the internship.

\section{Conclusion}

This study highlights the importance of adding training components on medical documentation to undergraduate medical curricula and having refresher trainings prior to the commencement of medical internship.

\section{Background}


A properly documented medical record is a vital component in good clinical care. A medical record lies as a core of health information system in the hospital. Medical document is a record pertaining to clinical assessment, medical care, professional judgment and critical thinking by a health professional in relation to providing patient care(Farhan et al., n.d.). Medical documentation may include written or electronic health records, observation charts, outcomes following treatment, check lists. The information providing through the medical document is definitely valuable. Ultimately the value of health records depends on the completeness of the record. Providing 'paper-based written documentation', is practiced in many developing countries. However, the process of documentation and issuing to the patient following medical care is given less priority by many health care providers around the world.

It is mandatory for medical graduates to complete a one-year internship to get the full registration from Sri Lanka Medical Council to practice medicine in Sri Lanka. They are required to work under the supervision of a consultants in secondary or tertiary care hospitals as intern medical officers during this internship period. One year Internship period is comprised of two 6-monthly appointments. All medical graduates who successfully completed their final MBBS examination obtain internship placements.

Correct medical documentation practices is of utmost important in the healthcare delivery which should be practiced by all medical professionals including those who are doing the internship. A descriptive study done among 207 medical students at Mazandaran University of Medical Sciences, Iran was found $77.8 \%$ of the participants had low knowledge about medical records documentation and $54.1 \%$ of them did not have good attitude on completion of medical records(Siamian et al., 2008). The findings of an institution based cross sectional quantitative study among 260 health professionals in University of Gondar Hospital indicated that health professionals have somewhat poor documentation practice and unfavorable attitude to medical documentation practice(Belay \& Rao, 2016). The study also confirmed the importance of attitude towards medical documentations. Study done in 2016 to find out perception of Sri Lankan pre intern doctor on writing diagnosis card highlighted that medical undergraduate curriculum should be needed to address the issue and should be ensured adequate training during undergraduate period (Society for Health Research and Innovations, 2019).

Different forms of information communication technologies (ICTs) are being applied and used in health care facilities to strength the health system. As for the potential benefits, the 'Electronic medical record Systems' are being implemented rapidly in healthcare settings in different countries(Lakbala \& Dindarloo, 2014; Olok et al., 2015; Pole, 2010; Rathnayake \& Hewapathirana, n.d.). In Sri Lanka, recently some health care facilities have started electronic documentation (Pole, 2010). Sri Lanka is a well-known country with better health indices compared with other countries in South Asia. Health Information Systems have an integral role in better health care. A study which was conducted in four government hospitals to explore the impact of 'electronic health records' revealed that service delivery can be improved with the introduction of electronic health information system. The study also has found that, health staff have highly accepted that system (Rathnayake \& Hewapathirana, n.d.). 
The 'diagnosis card', can be explained as the take-home discharge summary given to the in-door patient before leaving hospital. It is a source of information to the patient as well as the health care providers, at future encounters with health services. Even though some hospitals in Sri Lanka have started electronic health documentation, most of the health care facilities are still practicing paper based manual health documentation at discharge. It is usually done by the most junior doctor on duty. However, there is a lack of a specific mechanism to monitor the accuracy and quality of a diagnosis card. There is a paucity in Sri Lankan literature to assess attitudes and perception among doctors on medical documentation.

Many countries have recognized the importance of the time period between university graduation and commencement of internship and have taken appropriate measures to get the maximum benefit of that (General Medical Council, 1993; Medical Council of New Zealand, 2003; Dunedin School of Medicine, 2007; Faculty of Medical and Health Sciences, 2007; Royal Australasian College of Physicians, 2007; Wellington School of Medicine, 2007). In Sri Lanka for the first time in 2013, the Government Medical Officers' Association with the support of Ministry of Health initiated the 'Good Intern Programme' - a comprehensive preparatory programme for the internship, to achieve this locally. Several postgraduate academic colleges and Society for Health Research and Innovation are among the other collaborators of the Good Intern Programme. Attitudes and perception on medical documentation among pre-interns were assessed before starting the Good Intern Programme.

Objective of the study was to determine attitude and perception towards medical documentation among pre intern doctors.

\section{Methods}

\section{Study design}

A cross sectional study was carried out among pre interns who graduated with Bachelor of Medicine, Bachelor of Surgery (MBBS) degrees in 2019 from Sri Lankan universities and foreign medical graduates who have successfully completed the requirements for medical internship.

\section{Study setting}

Surveys were distributed among the participants of Good Intern Programme- the pre-intern skill development programme. Sri Lankan medical Faculties produce approximately 1000 medical graduates per year. All schools offer similar 6-year undergraduate programmes. The first 3 years are predominantly a mix of taught medical science and clinical principles, and the years 4 and 5 are focused on attachments through a variety of clinical attachments supplemented by lectures, tutorials and practical sessions. The main barrier exams are taken at the end of fifth year and following successful completion, students become trainee interns attached to clinical teams; namely general medicine, general surgery, obstetrics and gynaecology, paediatrics.

\section{Study population and sample size}


Pre interns who joined for the Good Intern Programme, conducted by GMOA in collaboration with Ministry of Health, The College of Anesthesiologists of Sri Lanka, Ceylon College of Physicians, Society for Health Research and Innovations in year 2020 were invited to participate for this study. The number of pre intern doctors who participated for the study were 641.

\section{Data collection and analysis}

A pre-tested self-administered questionnaire was used to collect the data. The Questions were identified, piloted and validated through a focused group prior to administration. Data were entered into a datasheet in Statistical Package for Social Sciences (SPSS) version 25. Descriptive analyses were done. Following entry of the data incomplete entries were identified. Those were corrected based on original questionnaire. Frequency distribution was examined. Attitudes and perception towards medical documentation among pre intern doctors were assessed. Descriptive data were presented as proportions.

\section{Ethics approval}

Ethical review was obtained from the Faculty of Medicine, University of Sri Jayawardenapura.

\section{Results}

Six hundred forty-one pre interns participated for the study. Mean age of the participants was 27.6 (SD 1.4) years. As shown in Table 1, majority of the pre-interns were females (66.5\%).

Table 1

Frequency distribution of the
study population by gender

\begin{tabular}{|lll|}
\hline Gender & No. & $\%$ \\
& $(\mathbf{n = 6 4 1 )})$ \\
\hline Female & 426 & 66.5 \\
\hline Male & 215 & 33.5 \\
\hline
\end{tabular}

Table 2 describes the frequency of attitudes towards writing diagnosis card.

Table 2

Frequency distribution of attitudes towards writing diagnosis card among study participants

\begin{tabular}{|c|c|c|c|}
\hline \multirow[t]{2}{*}{ Variable } & YES & NO & \multirow{2}{*}{$\begin{array}{l}\text { Don't } \\
\text { know } \\
(\%)\end{array}$} \\
\hline & No (\%) & No (\%) & \\
\hline $\begin{array}{l}\text { If a patient leaves against medical advice, would you } \\
\text { give him a diagnosis card? }\end{array}$ & $429(66.93)$ & $152(23.71)$ & $60(9.36)$ \\
\hline $\begin{array}{l}\text { For simple viral fever (One day hospital admissions) } \\
\text { you have to give diagnosis cards }\end{array}$ & \multicolumn{2}{|c|}{ 588(91.73) 33(5.15) } & $20(3.12)$ \\
\hline
\end{tabular}


Majority (66.93\%) of pre- interns perceived that if a patient leaves against medical advice, it is a duty of the doctor to issue a diagnosis card to the patient. Majority $(91.73 \%)$ of them believed that they have to give a diagnosis card even for the for simple viral fever (One day hospital admissions).

The mean scores of attitudes on 'Patient point of view when giving a diagnosis card is important' was $9.20(\mathrm{SD}=1.55)$ while 'Doctor point of view when giving a diagnosis card is important' was $9.83(\mathrm{SD}=$ 0.60) (Table 3).

Table 3

Mean scores of attitudes towards medical documentation among study participants

\begin{tabular}{|lll|}
\hline Variable & Mean* & SD \\
\hline Patient point of view when giving a diagnosis card is important & 9.20 & 1.55 \\
\hline Doctor point of view when giving a diagnosis card is important & 9.83 & 0.60 \\
\hline SD = Standard deviation * minimum = 1, maximum = 10 & & \\
\hline
\end{tabular}

As shown in Table 4, majority (69.42\%) of pre- interns have got a chance to participate for any training on writing diagnosis cards within last 3 years. Majority (74.26\%) of them perceived that they have received an adequate training in diagnosis card writing so far.

Table 4

Frequency distribution of training on medical documentation among study participants

\begin{tabular}{|llll|}
\hline Variable & Yes & No & \multicolumn{1}{c|}{$\begin{array}{l}\text { Don't } \\
\text { know }\end{array}$} \\
\hline $\begin{array}{l}\text { Within last 3 years did you undergo any training on writing } \\
\text { diagnosis cards }\end{array}$ & $\begin{array}{l}\text { n } \\
\text { (\%) }\end{array}$ & $\mathbf{n}$ (\%) \\
\hline $\begin{array}{l}\text { Do you think that you have received an adequate training in } \\
\text { diagnosis card writing so far? }\end{array}$ & $\begin{array}{l}476(69.42) \\
(18.71)\end{array}$ & $12(1.87)$ \\
\hline
\end{tabular}

Majority (58.13\%) of participants have mentioned as they learnt to write diagnosis card by observing during ward work. Only $16.22 \%$ and $1.09 \%$ have undergone training during undergraduate period and workshops by professional colleges respectively (Table 5) 
Table 5

Frequency distribution of the study population by where they learnt to write a diagnosis card

\begin{tabular}{|ll|}
\hline Variable & \multicolumn{1}{c|}{ Number (\%) } \\
\hline Observing during ward work & $379(58.13 \%)$ \\
\hline Informal training by consultants or medical officers & $116(18.10 \%)$ \\
\hline By lectures during undergraduate training & $104(16.22 \%)$ \\
\hline Workshops by professional colleges & $35(5.46 \%)$ \\
\hline Other & $7(1.09 \%)$ \\
\hline
\end{tabular}

As shown in Table 6, majority (88.3\%) of participants perceived that they need a training on proper way of writing a diagnosis card prior to the internship.

Table 6

Frequency distribution of perception on requirement of a proper training on writing a diagnosis card among the participants

\begin{tabular}{|llll|}
\hline Variable & Yes & No & $\begin{array}{l}\text { Don't } \\
\text { know }\end{array}$ \\
& $\begin{array}{l}\text { No } \\
(\%)\end{array}$ & $\begin{array}{l}\text { No } \\
(\%)\end{array}$ & No (\%) \\
\hline $\begin{array}{l}\text { Do you feel that you need a proper training of writing a } \\
\text { diagnosis card }\end{array}$ & $\begin{array}{l}566(88.30) \\
50(7.80)\end{array}$ & 25(3.90) \\
\hline
\end{tabular}

Majority (52.26\%) of participants perceived that they have satisfactory level of competency in writing a diagnosis card while $39.62 \%$ and $4.06 \%$ of the pre interns perceived that they have good and excellent level of competency in writing diagnosis cards respectively (Table 7)

Table 7

Frequency distribution of perceived competency in writing a diagnosis card

\begin{tabular}{|c|c|c|c|c|c|c|c|}
\hline Variable & $\begin{array}{l}\text { Excellent } \\
\mathrm{n}(\%)\end{array}$ & $\begin{array}{l}\text { Good } \\
\text { n (\%) }\end{array}$ & $\begin{array}{l}\text { Poor } \\
\text { n } \\
(\%)\end{array}$ & $\begin{array}{l}\text { Satisfactory } \\
\text { n (\%) }\end{array}$ & $\begin{array}{l}\text { Very } \\
\text { poor } \\
n \\
(\%)\end{array}$ & $\begin{array}{l}\text { Don't } \\
\text { know } \\
\text { n (\%) }\end{array}$ & $\begin{array}{l}\text { Unassessed } \\
\mathrm{n}(\%)\end{array}$ \\
\hline $\begin{array}{l}\text { How is your } \\
\text { competency in } \\
\text { diagnosis card } \\
\text { writing }\end{array}$ & $\begin{array}{l}26 \\
(4.06)\end{array}$ & $\begin{array}{l}25422 \\
(39.62) \\
(3.43)\end{array}$ & & $\begin{array}{l}3352 \\
(52.26)(0.31)\end{array}$ & & & $\begin{array}{l}11 \\
(0.16)(0.16)\end{array}$ \\
\hline
\end{tabular}

\section{Discussion}

To the best of the researchers' knowledge, attitudes and perception on medical documentation among pre interns has not been assessed in Sri Lanka before commencing the Good Intern Programme. The Good 
Intern Program, is well organized training which provides an opportunity to improve the transition of Sri Lankan medical graduates using a multi-modal and sustainable methodology. The results of this study showed attitudes and perception towards medical documentation among the participants.

Majority (52.26\%) of participants perceived that they have satisfactory level of competency in writing a diagnosis card. Majority of them perceived that they have received an adequate training on diagnosis card writing so far. These findings on attitudes and level of competency in writing diagnosis cards are in line with several other studies among healthcare workers(Ayele et al., 2021; Kalengo,2015; Nakate et al., 2015). A study to assess the healthcare workers' attitude towards documentation in Hawassa City administration public hospitals, Southern Ethiopia revealed that $58.8 \%$ [95\% Cl of 54.5-63.7\%] of them had a favourable attitude towards documentation(Ayele et al., 2021). Also, it was found the knowledge as a significant factor with attitude towards documentation. This finding was consistent with the findings of the current study.

Attitude and Practice Towards Method of Medical Record Documentation has been demonstrated among Iranian Medical Students. The study has concluded that more than half of the study participants as not having a good attitude on medical documentation. It was also shown that $77.8 \%$ of the medical students had low knowledge on medical records documentation. The study interpreted it as lack of awareness of the students towards the method of medical records documentation, not considering the completion of records in evaluation of the students can affect their practice. The finding on attitude on medical documentation was lower than the finding of the current study The possible reason for this variation might be in the current study majority of pre-interns have got a chance to participate for any training on writing diagnosis cards within last 3 years and majority (74.26\%) of them perceived that they have received an adequate training in diagnosis card writing so far.

A study done to assess the current medical documentation practice of health professionals and attitude towards it at University of Gondar Hospital, Gondar, North West Ethiopia, 2016 concludes that health professionals have somewhat poor documentation practice and unfavourable attitude to medical documentation. The inconsistency might be due to the knowledge difference among study participants and other organizational differences.

Medical internship is the mandatory initial step in the development of a medical professional after passing out from the medical school. During this period, it is mandatory for interns to contribute significantly to all clinical duties and medical documentation in the ward. Many medical schools have already introduced pre-internship periods to their curricula, as well as many hospitals encourage a period of shadowing prior to the year of internship to have safe trainee changeovers (Academy of Medical Royal Colleges, 2016). Evidence shows such programs have a significant positive effect on the pre-interns. In the current study significant number of participants perceived that they need a training on proper way of writing a diagnosis card prior to the internship. The study suggests pre intern year can be used to prepare medical student to be a skilled intern doctor by improving their knowledge on proper medical 
documentation and thereby attitudes. The Good Intern Program can effectively contribute in bridging the gap by further enhancing their knowledge and attitudes.

\section{Conclusion}

This study highlights the importance of adding training components on medical documentation to undergraduate medical curricula and having refresher trainings prior to the commencement of medical internship.

\section{Abbreviations}

ICTs

Information Communication Technologies

GMOA

Government Medical Officers' Association

MBBS

Bachelor of Medicine

Bachelor of Surgery

$\mathrm{MOH}$

Ministry of Health

SD

Standard Deviation

\section{Declarations}

\section{Acknowledgements}

This work was supported by GMOA, in collaboration with SHRI and Ministry of Health, Nutrition and Indigenous Medicine

\section{Funding}

No

\section{Availability of data and materials}

All data generated or analyzed during this study are included in this published article and as a supplementary file.

\section{Contributions}

ABP and PKBM conceptualized the research. AlH, WSPA did the data analysis. AlH, WSPA, HMBHD, AM drafted the manuscript. ABP, PKBM, AlH, WSPA, HMBHD, AM, AG, PM, CE, JMSDR, PC, LJW, KW, NDSKW 
and WIUJ contributed to interpretation of the data, substantively revised the manuscript and approved the final version.

\section{Ethics declarations}

\section{Ethics approval and consent to participate}

Ethical approval was obtained from the Ethical Review Committee, Sri Jayawardanapura Faculty, Sri Lanka. All methods were performed in accordance with the relevant guidelines and regulations (e.g. Declaration of Helsinki). Informed consent was obtained from all subjects.

\section{Consent for publication}

Not applicable

Competing interests; The authors declare that they have no competing interests.

\section{References}

1. Academy of Medical Royal Colleges. (2016). Recommendations for Safe Trainee Changeover. https://www.aomrc.org.uk/reports-guidance/recommendations-for-safe-trainee-changeover-0613/

2. Ayele, S., Gobena, T., Birhanu, S., \& Yadeta, T. A. (2021). Attitude Towards Documentation and Its Associated Factors Among Nurses Working in Public Hospitals of Hawassa City Administration, Southern Ethiopia. SAGE Open Nursing, 7. https://doi.org/10.1177/23779608211015363

3. Belay, A., \& Rao, Y. N. (2016). Medical Documentation Practice of Health Professionals and Attitude towards it at University of Gondar Hospital, Gondar, North West Ethiopia. International Journal of Advances in Applied Sciences (IJAAS), 5(4), 157-162.

4. Dunedin School of Medicine. 2007. 2006-2007 Trainee intern handbook. Dunedin: Dunedin School of Medicine, University of Otago.

5. Farhan, J., Al-Jummaa, S., Al-Rajhi, A., Al-Rayes, H., \& Al-Nasser, A. (n.d.). Documentation and coding of medical records in a tertiary care center: a pilot study. In Ann Saudi Med (Vol. 25, Issue 1). http://www.saudiannals.net

6. General Medical Council. 1993. Tomorrow's doctors. London: General Medical Council. pp 19-20.

7. Kalengo, N. (2015). Knowledge attitude and practice among nurses towards documentation of fluid balance chart at UTH Lusaka. http://dspace.unza.zm/handle/123456789/ 4043

8. Lakbala, P., \& Dindarloo, K. (2014). Physicians' perception and attitude toward electronic medical record. SpringerPlus, 3(1), 1-8. https://doi.org/10.1186/2193-1801-3-63

9. Medical Council of New Zealand. 2003. Expectations of interns. Medical Council of New Zealand handbook. Wellington: Medical Council of New Zealand.

10. Olok, G. T., Yagos, W. O., \& Ovuga, E. (2015). Knowledge and attitudes of doctors towards e-health use in healthcare delivery in government and private hospitals in Northern Uganda: A cross-sectional 
study. BMC Medical Informatics and Decision Making, 15(1). https://doi.org/10.1186/s12911-0150209-8

11. Nakate, G., Dahl, D., Drake, K. B., \& Petrucka, P. (2015). Knowledge and attitudes of select Ugandan nurses towards documentation of patient care. African Journal of Nursing and Midwifery, 2(1), 056065.

12. Pole, D. (2010). Electronic Patient Records in Sri Lankan Hospitals. Sri Lanka Journal of Bio-Medical Informatics, 1(1), 43. https://doi.org/10.4038/sljbmi.v1i1.1466

13. Rathnayake, S., \& Hewapathirana, R. (n.d.). IMPACT OF ELECTRONIC HEALTH RECORDS IN SRI LANKA: CASE STUDY OF FOUR GOVERNMENT HOSPITALS.

14. Royal Australasian College of Physicians. 2007. RACP professional qualities curriculum. Australia: Royal Australasian College of Physicians.

15. Siamian, H., no, B., Bala Ghafari, A., \& Aligolbandi, K. (2008). Study on Rate of Knowledge, Attitude and Practice of Medical Students Towards Method of Medical Records Documentation. World Journal of Medical Sciences, 3(1), 24-27.

16. Society for Health Research and Innovations. (2019, September 1). Good Intern Programme Research Articles. SHRI. Retrieved November 5, 2021, from https://shri.lk/good-intern-programme-researcharticles/

17. Wellington School of Medicine. 2007. Trainee intern handbook. Wellington: Wellington School of Medicine, University of Otago.

\section{Supplementary Files}

This is a list of supplementary files associated with this preprint. Click to download.

- GoodlnternProgramme2020MedicaldocumentationSriLanka.xlsx 